\title{
Legal Certainty for The Authority of The Commission For The Supervision Of Business Competition (KPPU) In The Settlement Of Business Competition Disputes
}

\author{
Junaidi \\ \{junaidievy@yahoo.com\} \\ Doctor of Law, Universitas Jayabaya, Jakarta, Indonesia
}

\begin{abstract}
Business conspiracy is one of unfair business competition practices. To prevent this practice, Business Competition Supervisory Commission was established to control business competition practices in Indonesia. The roles of this independent commission are regulated in Article 35 and Article 36 of Law Number 5 of 1999 concerning Prohibition of Monopolistic Practices and Unfair Business Competition. This law also regulates the practices of unfair business competition including business conspiracy as regulated in Article 22 to Article 24. The Business Competition Supervisory Commission does not serve as a "Law Enforcement Institution"; therefore, the commission is not allowed to conduct compulsory actions to summon any parties or carry out executions. As stated in the Article 48 and Article 49 of Law Number 5 of 1999, this commission can give criminal sanctions for violators. In facts, many decisions made by this commission were cancelled due to objections stipulated in Article 44 of Law Number 5 of 1999 filed by the violating parties, resulting in legal uncertainty. To address this problem, a revision should be made to Law Number 5 of 1999 in order to provide legal firmness and certainty in business competition law, including the procedural law that applies.
\end{abstract}

Keywords: Unfair Business Competition; Legal Certainty; Business Competition Supervisory Commission's Authority

\section{Introduction}

Unfair business competition is competition between business actors in carrying out production and or marketing activities of goods or services, carried out dishonestly or against the law or obstructing business competition [1]. Law Number 5 of 1999 concerning the Prohibition of Monopolistic Practices and Unfair Business Competition regulates unfair business competition and the establishment of an independent commission, namely Commission for the Supervision of Business Competition (Komisi Pengawas Persaingan Bisnis/KPPU). The task and authority are to supervise the implementation of the law itself of the latter.

The law provides regulations on agreements, prohibited activities, and the dominant position of a business actor. One of the prohibited activities is a conspiracy. Law Number 5 of 1999 concerning Prohibition of Monopolistic Practices and Unfair Business Competition defines conspiracy, or business conspiracy, as a form of cooperation between business actors and other business actors to control the relevant market for the interests of conspiring business actors.

The enactment of Law Number 5 of 1999 has resulted in KPPU having several powers as other judicial institutions. These authorities are the investigation authority, enforcement 
authority, and litigation authority [2]. KPPU is a supervisory agency for the implementation of laws, but KPPU is not a law enforcement apparatus in the criminal field such as police, prosecutors and judges, who have the power to compel parties to attend a trial. Article 36 of Law Number 5 of 1999 regulates the authority of KPPU as only an initial investigator and investigator of criminal jurisdiction. This authority can be used as a legal basis by KPPU to find the material truth, whether or not the parties have violated Law Number 5 of 1999.

An important authority owned by KPPU is the authority to impose sanctions. In giving sanctions against Law Number 5 of 1999, KPPU should conduct an initial investigation and investigation process. Sanction decisions given by KPPU are final and binding. However, in Article 44 of Law Number 5 of 1999, offenders who object to the KPPU's decision can file legal remedies for objections in the district court or the supreme court. Many KPPU decisions were cancelled by the district court, making the offending party free from sanctions for violating the law. Due to the weaknesses in Law Number 5 of 1999 itself, this fact resulted in some disadvantages for the reporting party. Not only do they suffer from loss and often not get legal certainty, they also do not get legal protection if the act of violating Law Number 5 of 1999 was declared not proven by the District Court. There are still differences in viewpoints between KPPU investigators and court officials in enforcing the law on unfair business competition.

KPPU as a "supervisory institution" for the law has limitations in proof, summoning the parties, executing decisions, and imposing sanctions. In summoning the parties, KPPU does not have the power of coercion like the court, police and prosecutors. However, based on Law Number 5 of 1999, KPPU has much authority in this institution. Against that background, problems in business competition must be studied comprehensively, especially regarding procedural law [3].

\section{Research Methods}

This research is juridical normative, namely research focusing on examining the application of the rules or norms in positive law [4]. Juridical normative research is an approach that uses the concept of positive law. This concept views that law is identical to written norms made and promulgated by the competent institution or official. This conception views law as a normative system that is independent, closed, and detached from the real-life of society [5]

\section{Findings and Discussion}

\section{The Authority of the Commission for the Supervision of Business Competition (KPPU) in Investigating Business Conspiracy}

The authority given to KPPU to enforce the law in the world of business competition is enormous. KPPU's duties and authorities include the executive, judiciary, legislative and consultative sectors [6]. The given authority has resulted in KPPU having functions such as a consultative, judicial, legislative and executive institution [7]. The position of KPPU in the legal system in Indonesia is a public institution that holds a judicial and administrative act (i.e., judicial authority, which is administrative). This position can be seen in Law Number 5 of 1999 , which state that the juridical duties of KPPU are enforcing business competition law. KPPU is 
given the authority to apply business competition law through the process of initial investigation, investigation, and decision-making [8].

KPPU is not a super body with the current law. Ita authority is to report, investigate, prosecute, and make decisions that raises a problem. These powers are different from those of the police, attorney and courts [9]. In Law Number 5 of 1999, the authority of KPPU in investigating business conspiracies is regulated in Article 38 to Article 46 regarding procedures for handling cases. KPPU gives sanctions to business actors who violate Law Number 5 of 1999 concerning the Prohibition of Monopolistic Practices and Unfair Business Competition. These sanctions have two legal aspects: criminal law and civil law. Article 43 states the criminal law by ordering the KPPU to submit its decision to investigators. This action is implementing criminal law to business actors who violate criminal acts. The submission to investigators is carried out because KPPU is not authorized to impose criminal sanctions.

Meanwhile, regarding civil law, KPPU requests District Court for imposing the administrative sanction. The KPPU's authority has been affirmed through the Constitutional Court Decision Number 85/PUU-XIV/2016. This decision affirms that the KPPU, as an administrative institution, has an authority that is not the same as a judicial institution in carrying out law enforcement pro justitia [10].

\section{Imposing Sanctions by the Business Competition Supervisory Commission (KPPU) against Business Conspiracy}

KPPU is a special institution that has a dual role: to create security and order in the world of business competition and maintain and protect the climate of business competition. KPPU also functions like law enforcement in the world of business competition. However, KPPU is not a special court institution for business competition [11]. Business actors who commit unhealthy business conspiracy and have violated Law Number 5 of 1999 may be subject to administrative and criminal sanctions. Administrative sanctions are regulated in Article 47 of Law Number 5 of 1999, while the main criminal sanctions are regulated in Article 48 and additional penalties in Article 49 of Law Number 5 of 1999. The nature of violations in Law Number 5 of 1999 is imperative. Based on Article 44 paragraph (4) and (5), the violation is civil as long as the offender accepts the KPPU decision and executes the administrative decision that KPPU has decided to the parties [12].

To the parties who do not implement the KPPU's decision, KPPU must submit a request for investigation to the investigators. As a result, the lex specialist of Law Number 5 of 1999 has changed to become lex generalis. In this case, the investigation is already in criminal procedural law (KUHAP). Unimplemented KPPU's decision is sufficient initial evidence for the investigator to carry out the investigation [13]. Apart from administrative sanctions in Law Number 5 of 1999, the law also regulates criminal sanctions. Article 48 regulates the main criminal sanctions, as follows:

1. The threat of a fine of a minimum of Rp.5,000,000,000.00 (five billion rupiahs) and a maximum of 25,000,000,000.00 (twenty-five billion rupiahs) or imprisonment in lieu of a fine of up to 5 (five) months. Those who are threatened are people committing several acts against the business competition law as follows:

a. Committing the prohibited price-fixing (Article 5-8);

b. Making prohibited closed agreements (Article 15);

c. Committing prohibited buying and selling (Article 20);

d. Committing fraud in determining the components of the price of goods (Article 21);

e. Committing prohibited conspiracy (Articles 22-24);

f. Abusing a dominant position (Article 25). 
2. The threat of a fine of a minimum of Rp.1,000,000.0000.00 (one billion rupiahs) and a maximum of Rp. 5,000,000,000.00 (five billion rupiahs) or imprisonment in place of a fine of up to 3 (three) months. Those who are threatened are people committing several acts against the business competition law as follows:

a. Refusing to submit evidence in an investigation and/or examination;

b. Refusing to be examined for an investigation and/or examination process;

c. Refusing to provide the information required in the examination and/or investigation;

d. Hinder the investigation and/or examination process

Article 49 of Law Number 5 of 1999 concerning Prohibition of Monopolistic Practices and Unfair Business Competition regulates criminal sanctions by referring to Article 10 of the Criminal Code (KUHP). Violations of criminal law as stipulated in Article 48 can be subject to additional penalties in the form of :

1. Revocation of business license; or

2. Prohibition on business actors who have been proven to have violated this law from holding positions of directors or commissioners for at least 2 (two) years and a maximum of 5 (five) years; or

3. Termination of certain activities or actions that cause losses to other parties.

4. The imposition of sanctions for violations of Law Number 5 of 1999, as regulated in Article 36, can only provide administrative sanctions. Based on Law Number 5 of 1999, KPPU's authority to impose sanction is limited to administrative sanctions, because in principle, KPPU is not authorized to impose criminal or civil sanctions [14].

Constraints and Efforts to Enforce Business Competition Law in Creating Legal Certainty Enforcement of business competition law is experiencing obstacles in its application because [15]:

1. The statutory provisions are not comprehensive and have many weaknesses in their implementation.

2. Human resources come from the law enforcement institution that is regarded as the most corrupt institution in Indonesia by society.

3. KPPU has a law enforcement function in the field of business competition law, but KPPU does not have a role as a judicial institution in business competition. Therefore, KPPU is not authorized to impose criminal and civil sanctions because it is only an administrative institution. The sanctions imposed are only administrative ones.

In settlement of business competition disputes, the KPPU's authority to carry out initial investigations and impose sanction is ineffective because such decisions can be objected to and even be overturned by the District Court. Broadly speaking, the obstacles in enforcing business competition law include:

1. An institution that is responsible for implementing Law Number 5 of 1999

KPPU is an institution for supervising business competition [16]. It is an independent institution and has a responsibility to the President [17]. The KPPU's authorities are: receiving reports on allegations of monopolistic practices and unfair business competition, conducting research, investigating, deciding and imposing sanctions on business actors who violate Law Number 5 of 1999 [18].

2. Business actors

Business actors suspected of committing violations are instructed to submit the required documents [19]. KPPU will study these documents and then conduct investigations on these 
business actors. KPPU will summon all parties involved, including expert witnesses [20], and then consider whether the business actor is proven to have violated the law or not [21].

KPPU is an institution that is authorized by Law Number 5 of 1999, whose task is to supervise law enforcement in business competition. KPPU has the authority to decide on business actors or business activities that have harmed the public and the public interest. The decisions that the KPPU has given to business actors proven to have violated Law Number 5 of 1999 cannot be fully implemented. Many KPPU decisions cannot be executed. This is because they are constrained both normatively and practically.

The substance of business competition law in Law Number 5 of 1999 consists of both material law and formal law (procedure). Formal laws governing legal proceedings are formal and compelling. Therefore, they must be regulated in a clear and detailed manner by law. Law enforcement regulated in Law Number 5 of 1999 must be amended or revised, covering substance, institution and procedural law. The amendment of Law Number 5 of 1999 will strengthen the function and authority of KPPU in enforcing the law. In enforcing business competition law, strong and independent authority is needed. Besides, KPPU and the District Court have to communicate with each other to talk about the execution of KPPU's decisions. This is done to implement Law Number 5 of 1999 to provide legal certainty for the parties involved in the dispute.

\section{Conclusion}

KPPU is tasked with enforcing Law Number 5 of 1999 concerning the Prohibition of Monopolistic Practices and Unfair Business Competition. It also has authority which is regulated in Article 36. In the issuance of decisions in the form of sanctions by KPPU, many KPPU decisions can be overturned by the District Court through objection and cassation. KPPU decisions toward which objections and cassation are not filed cannot be executed because KPPU does not have the authority to force the parties to implement the decision.

The obstacles faced in enforcing business competition law are related to (1) KPPU, especially Law Number 5 of 1999; and (2) the business actors. Efforts that can be made to provide legal certainty are to revise Law Number 5 of 1999 . The revision aims to create a synchronization and harmonization between Law Number 5 of 1999 and other laws in regulating the material and formal laws of KPPU in enforcing business competition law.

\section{References}

[1] https://klikgtg.wordpress.com/category/hukum-bisnis/

[2] Hakim, Abdul., Garuda Nusantara \& Benny K. Herman., (1999) Analisis dan Perbandingan UndangUndang Monopoli, Jakarta : Elex Media Komputindo.

[3] Ibrahim, Johny. (2007) Hukum Persaingan Usaha - Filosofis, Teori dan Implikasi Penerapannya di Indonesia, Malang : Bayu Media, 2007, hlm. 1.

[4] (2006) Teori dan Metodologi Penelitian Hukum Normatif, Malang : Bayu Media.

[5] Soemitro, Ronny Hanitjo. (1998) Metodologi Penelitian Hukum dan Jurimetri, Jakarta : Ghalia Indonesia.

[6] Mochtar, Zainal Arifin. (2016) Lembaga Negara Independen : Dinamika Perkembangan dan Urgensi Penataannya kembali Pasca Amandemen Konstitusi, Jakarta : Rajawali Pers. 
[7] Wiradiputra, Ditha (2005) "Pengantar Hukum Persaigan Usaha", Dalam staff.ui.ac.id/system/files/users/ditha.wiradiputra61/material/mateikuliahhpu2005.pdf, diakses pada tanggal 15 Mei 2020, hlm 93.

[8] Ibid, hlm. 92.

[9] https://finance.detik.com/berita-ekonomi-bisnis/d3346253/“kppu-tidak-superbody” , diakses pada tanggal 15 Mei 2020.

[10] Putusan Mahkamah Konstitusi Republik Indonesia Nomor 85/PUU-XIV/2016 tentang Perluasan Makna Pihak Lain dalam Persaingan Usaha Tidak Sehat.

[11] Yuliana Juwita, "Larangan Persekongkolan Tender Berdasarkan Hukum Persaingan Usaha, suatu Perbandingan Pengaturan di Indonesia dan Jepang", Jakarta : Program Pascasarjana Fakultas Hukum Universitas Indonesia, 2012, hlm. 46.

[12] Elyta Ras Ginting, "Hukum Anti Monopoli (Analisis Perbandingan Undang-Undang Nomor 5 tahun 1999)", Bandung : PT. Citra Aditya Bakti, 2001, hlm. 115.

[13] Ibid, hlm. 116.

[14] Munir Fuady, "Hukum Anti Monopoli : Era Persaingan Sehat", Bandung : PT. Citra Aditya Bakti, 1999, hlm. 117.

[15] Aji Sekarmaji, "Tinjauan Atas Permasalahan yang Timbul dalam Penegakan Hukum Persaingan Usaha", Jurnal Hukum dan Pembangunan, tahun ke-39, Nomor 3, 3 Juli - September 2009, hlm. 410.

[16] Lihat Pasal 30 ayat (1) Undang-Undang Nomor 5 tahun 1999 tentang Larangan Praktik Monopoli dan Persaingan Usaha Tidak Sehat.

[17] Lihat Pasal 30 ayat (2) dan ayat (3) Undang-Undang Nomor 5 tahun 1999 tentang Larangan Praktik Monopoli dan Persaingan Usaha Tidak Sehat.

[18] Lihat Pasal 36 Undang-Undang Nomor 5 tahun 1999 tentang Larangan Praktik Monopoli dan Persaingan Usaha Tidak Sehat.

[19] Lihat Pasal 39 ayat (2) Undang-Undang Nomor 5 tahun 1999 tentang Larangan Praktik Monopoli dan Persaingan Usaha Tidak Sehat

[20] Lihat Pasal 39 ayat (4) Undang-Undang Nomor 5 tahun 1999 tentang Larangan Praktik Monopoli dan Persaingan Usaha Tidak Sehat.

[21] Lihat Pasal 43 ayat (3) Undang-Undang Nomor 5 tahun 1999 tentang Larangan Praktik Monopoli dan Persaingan Usaha Tidak Sehat 